\title{
Environmentally Conscious Manufacturing Through Total Cost Management
}

\author{
Al Y.S. Chen, (E-mail: Al_Chen@Ncsu.Edu), North Carolina State University \\ Helmut Hergeth, North Carolina State University \\ Gilroy J. Zuckerman, North Carolina State University
}

\begin{abstract}
Total Cost Management (TCM) is a business paradigm for managing all company resources and the activities that consume those resources with a focus on stimulating and managing improvements. We address the theoretical approach of TCM to environmental sustainability and present a practical case of using costing approaches to evaluate the sustainability of the manufacture of a recycled product. Decision aids, the QFD matrix, B2B e-commerce, allowable costs, and market-based pricing are employed to demonstrate that companies can apply the TCM model to integrate environmental policy as an essential component of corporate strategy to achieve and maintain competitive superiority.
\end{abstract}

\section{Introduction}

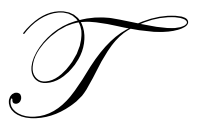

o sustain long-term profitability, corporate managers must consider environmental policy as an essential component of corporate strategy for achieving and maintaining competitive superiority. In response to increasing public concern for environmental issues, recent court decisions and more aggressive legislation and regulatory policies have greatly expanded corporations' potential liability. Thus, corporations need to reconsider their environmental efforts and to proactively manage, rather than react to, environmental problems.

Total cost management (TCM) is a business paradigm for managing all company resources and the activities that consume those resources with a focus on stimulating and managing changes. Under the TCM paradigm, companies can consider the entire environmental impact of their products by looking for substitutes for inputs that are hazardous and for processes that can reduce the generation of waste. TCM offers a systematic approach to continuously improve operations and reduce waste generation throughout the product life cycle. Firms will find such integration desirable to reduce costs, reduce liability, and minimize adverse community concerns over their operations.

\section{Background and Literature Summary}

The extant literature indicates that cost management systems of world-class manufacturers play a unique role. The focal point of such systems is to provide needed support for company-wide strategic planning and revitalization (Shank and Fisher, 1999). Advanced manufacturers must adopt an integrated cost planning approach with their marketbased strategic product development. World-class manufacturers perform extensive cost planning to manage costs through cost reduction at the product design and development stage. The fact that most cost decisions are made prior to production in the engineering design, prototype and vendor sourcing stages is the basis for this emphasis. This is the stage where many decisions are made that will eventually determine environmental costs.

Cost planning activities generally involve value engineering and target costing analyses. Value engineering examines the functions that products are to perform and then evaluates those functions with respect to customer demands and function costs (Monden and Hamada, 1991). Value engineering goes beyond the analysis of production costs and includes the analysis of a product's entire life-cycle to determine the cost implications of design and product development decisions in a particular product.

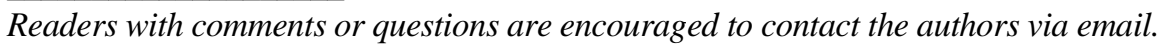


In addition, target cost analysis is often used to gather information and to foster commitment from all departments involved. Each new product, or major revision of an existing product, will be developed based on crossfunctional input from sales and marketing, engineering design, engineering production, and cost management. The formal target cost is jointly determined by all functions involved which is set between the allowable cost based on customers' expectation and the potential cost based on the current technology and production methods (Monden, 1989). As a result, the purposes of designating target costs are to encourage cost reduction and control and to achieve the corporation's strategic goals (Chen, et al., 1997a). In addition, target costing supports activity-based costing to develop the cost of quality data that promote quality being designed into products (Anderson and Sedatole, 1998).

To meet the challenge of environmental conservation and waste management, world class manufacturers must include environment policies into their strategically oriented, integrated systems (Hunt and Auster, 1990; Stratton, 1991). Studies of technologically intensive companies have shown that the key to achieving a sustainable competitive advantage is sound management of technological innovation. Technological innovation programs should be an element of a company's overall business strategy and unite activities in all functional areas including R\&D, product design, process design, manufacturing, marketing and environmental preservation (Burgelman and Maidique, 1988, Tushman and Moore, 1988). TCM creates the environment for cross-disciplinary cooperation and manages the process toward innovation and environmental preservation. In addition, TCM provides tools to incorporate changes in the views of business ethics and social responsibility (Chen et al., 1997b).

\section{Total Cost Management Approach to Sustainability}

TCM does not accept costs as "given" but instead as a point of reference upon which to constantly improve. The tools of environmental economics continue to remain useful, but they must be viewed as guides for improvement. Environmental economics is justifiably concerned with the externalities created by the divergence in private costs and social costs (Freeman et. al., 1992). TCM is more normative in viewing more of these costs as part of private costs. At the firm level, economic analysis focuses on the adjustment toward equality between the marginal private cost of control and the marginal cost (damage) to the firm. TCM is focused on learning to become more efficient in preventing pollution instead of correcting pollution, thereby shifting the marginal cost of control downward. TCM is also focused on recognizing that more cost "should" and will be borne by the firm, thus shifting the marginal damage upward. Combining these two directional shifts will continually move the firm toward (but not necessary to) zero pollution. Based on the target costing process outlined by Cooper and Slagmulder (1997), TCM offers the following features that promote the development of innovative environmentally friendly products.

\section{Establish Market-Based Pricing}

It has always been a risky and challenging task to develop profitable new products as companies face everincreasing competition. The development of innovative, environmentally friendly products would pose even more uncertainties because their market prospects are largely unknown.

Target costing is driven by market price and desired profits and thus, creates the critical alignment between the innovative products with the marketplace. TCM demands a highly disciplined process based on thorough market analysis of what customers want and what price they are willing to pay. In support of launching an innovative product its target price cannot be established in a vacuum but needs to be determined by external market factors, in particular, the strength of the new product compared to competitive offerings and market prices for comparable products. For the innovative environmentally friendly products, customers can be expected to pay more for them because these products offer more perceived value than their existing peers do. Research has shown that thirty percent of customers will pay up to 20 percent extra for the environmentally friendly products and many products (e.g., Green Vista, Eco-sport, Green Tag, green electricity) have commanded such price premiums (Wagner, 1993). TCM helps firms to better understand the availability of competitive products and their perceived values and to ensure the most realistic possible selling prices of the environmentally friendly products. 
Figure 1

Total Cost Management Factors in Environmental Costing

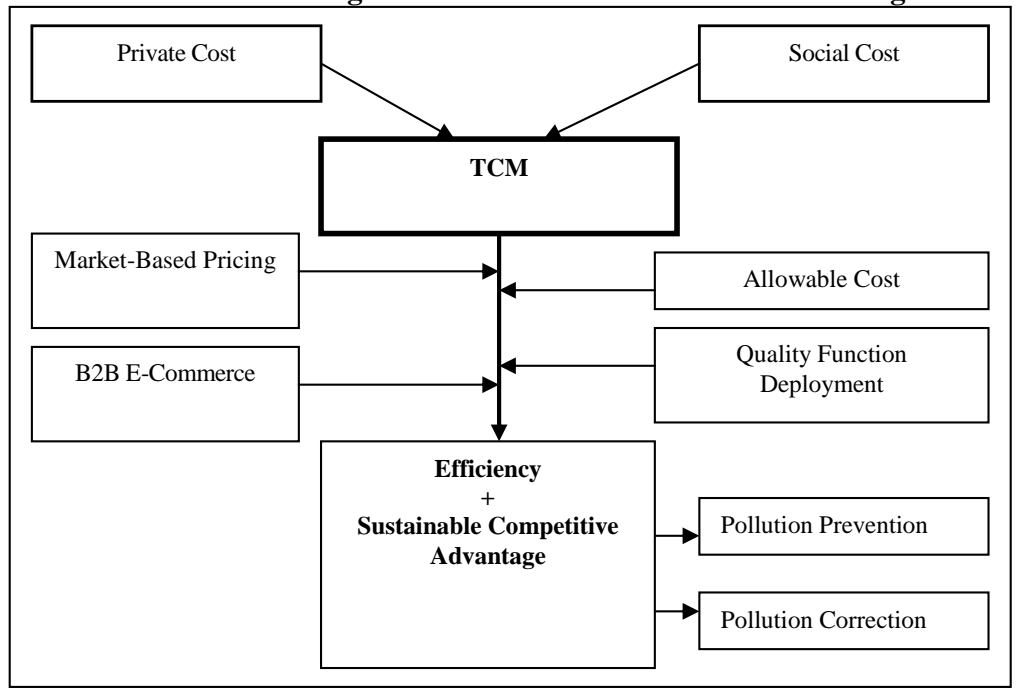

B2B E-commerce

The recent development of Internet and e-commerce open up many new opportunities for more free flow of information between suppliers of innovative products and their potential customers. The Internet enables the seamless flow of information through a web-based platform that links customers, suppliers, and contents for the benefits of all the partners participate in the supply chain. Solid Waste.com provided by VerticalNet Inc., for example, is an online community of suppliers, buyers and consultants that provide rich information about products, services, and technology concerning waste handling and disposal from consumer, commercial, and industrial sources. It provides the registered users the opportunities of conducting market analysis by interacting with those operators, technicians, engineers, and business executives who are active or have an interest in improving operations involving solid-waste handling and disposal. The Solid Waste site also offers B2B features such as "Request for Quote" (RFQ) that allow a firm to create responses online, track and manage responses and requests (invitations to quote, submit quotes, acceptances, rejections, etc.), and correspond online with potential buyers. Industry-based independent web sites (e.g., clickforsteel.com) offer competitive products' market price information. Auction sites such as RAGauction.com offers online bidding service, which provides Internet access to suppliers and buyers of the recycling industry. Online business-to-business e-commerce platforms such as Solid Waste.com and RAGauction.com makes it easier for a firm to determine the customer perceived value and, thus, help them to determine the new product's target price.

\section{Determine the Allowable Costs.}

The market-based target prices of the new products determined above become the driving force of new product design because:

Allowable cost $=$ Target price - Target profit margin

The target margin is established to ensure achievement of the company's long-term profitability ${ }^{1}$. Since the allowable cost is derived from external conditions, the risk is that the allowable cost will not be achievable with the existing product design and production facilities. In order to achieve allowable cost, an interactive process using the cost tables and quality function deployment (QFD) will be used and continuously updated to reflect the current and alternative materials and engineering methods. The cost tables contain detailed estimates of the costs of various parts or activities depending on the materials, manufacturing methods and functions involved (Yoshikawa, et. al., 1990). Quality function deployment is typically used for systematically analyzing the product features, component functions and customer preferences in a matrix format (Ansari et. al., 1997). Both cost tables and QFD are used to formulate a value index to direct the new product's value engineering activities to achieve the target costs $^{2}$. An example of constructing high-density textile particle boards for furniture application from recycled textile waste is used to demonstrate how QFD

\footnotetext{
${ }^{1}$ The target profit margin can be initially set based on the actual profit margin of the existing products and then adjusted for the perceived value of the new product based on market analysis.

${ }^{2}$ Ansari et. al. (1997) define value engineering as "an organized effort directed at analyzing the functions of the various components for the purpose of achieving these functions at the lowest overall cost without reduction in required performance, reliability, maintainability, quality, safety, recyclability, and usability."
} 
can direct value engineering activities to reduce the total product costs. In the example the QFD matrix also is used to aid in the evaluation of the original target market.

\section{QFD of High-Density Textile Particle Board for Furniture Application from Recycled Textile Waste}

The idea of evaluating the possibility of manufacturing high-density particleboard from recycled textile waste had two drivers. On the one side the manufacture of particleboard from wood chips requires the use of adhesives that contain toxins. On the other side the textile industry has long tried to recycle its waste material. In most cases it makes economic sense, but in some cases it is not possible and alternative uses have to be found. When alternative uses are not found, the waste material typically ends up on landfills, and synthetic materials do not decompose for a very long time.

Within the scope of TCM, the waste cost to the textile industry includes the cost of the wasted raw material including all processing cost up to the manufacturing step where the waste is generated and the disposal cost of landfilling the waste materials. The potential costs to wooden particleboard manufacturers for health hazards due to the release of formaldehyde is harder to determine. The case study concentrates on target costing concepts that are used in the product development steps for synthetic particleboard (Heinisch et. al., 2001). While a marketable product has not yet been produced, the results of the target costing analysis lead to implications in the manufacturing process as well as the marketing of the boards.

Following the process of target costing as described by the Consortium for Advanced Manufacturing International (CAM-I), a target price was established through market research and competitive analysis of wooden particleboard (Hergeth, 2001). The specific market niche was determined as outdoor construction panels because of the superior water resistance of synthetic materials. Tests had shown that the synthetic samples absorbed extremely low amounts of water, and therefore no deterioration of the product was to be expected. Customer requirements were determined through testing standards and discussions with building contractors. The price range for the particleboard in the market at the time of the study ranged from $\$ 11.59$ to $\$ 16.05$ for a 4 by 8 feet panel (5/8-inch thickness). 4-Layer plywood (stronger and better aesthetics, according to the contractors) sold for $\$ 17.47$ to $\$ 18.74$.

The Quality Function Deployment matrix (QFD matrix) links the customer requirements systematically with product components or functions. At the same time the customer requirements are ranked by relevance or importance, and the own product can be compared with competitor rankings as to how well the requirements are being fulfilled. Table 1 shows the customer requirement rankings for the requirements that were discussed with the potential users of the synthetic particleboard. The Relative Rankings show how much each of the requirements contributes to the overall requirements a potential customer has for the product. These rankings serve as a guide in product development, showing which needs ought to be addressed with how much effort.

The competitive ranking is based on some discussions with building contractors and to a large extent on the testing results that were performed on manufactured synthetic samples and on purchased wooden samples. The results are somewhat theoretical because the manufactured samples were small lab samples rather than full size 4 by 8 feet sheets.

Table 1 shows customer requirements, as they would be revealed through market research, and how important these requirements are to the customer on a 1 to 5 scale. These rankings are then set in proportion under relative rankings and can be compared with actual ratings of the products in the customers' minds (see: Competitive Ranking). In this case one can see some distinct problems of the synthetic particleboard at this stage of the development. The comparison with the wooden competitor clearly shows areas of the product that require further improvement or at the very least they show the necessity to make new tools to replace nailing and screwing more appealing. From a marketing point of view the table also shows that the areas with competitive advantage are not ranked as very important in the contractor market. As a result of this analysis, the target market should be redefined with a focus on areas that require water resistance, shaping, and less dependence on traditional nailing or screwing. 
Table 1:

Customer Ranking of Particleboard Requirements

\begin{tabular}{|l|c|c|c|c|}
\hline $\begin{array}{l}\text { Customer } \\
\text { Requirement }\end{array}$ & Customer Ranking & Relative Ranking & \multicolumn{2}{|c|}{ Competitive Ranking } \\
\hline & & & $\begin{array}{c}\text { Wooden } \\
\text { Particleboard }\end{array}$ & $\begin{array}{c}\text { Synthetic } \\
\text { Particleboard }\end{array}$ \\
\hline Strength & 5 & 4 & 4 \\
\hline Screw Withdrawal & 5 & $14.3 \%$ & 5 & 3 \\
\hline Nail Withdrawal & 5 & $14.3 \%$ & 5 & 4 \\
\hline Ease of Nailing* & 4 & $14.3 \%$ & 4 & 2 \\
\hline Ease of Screwing* & 3 & $8.6 \%$ & 4 & 1 \\
\hline Weight/Ease of Handling & 3 & $8.6 \%$ & 2 & 4 \\
\hline Water Resistance & 4 & $11.4 \%$ & 1 & 5 \\
\hline Ability to Shape** & 2 & $5.7 \%$ & 5 & 4 \\
\hline Ability to Tool*** & 4 & $11.4 \%$ & & 4 \\
\hline
\end{tabular}

* Ease of Nailing and Screwing refers to the ability to use traditional nails and screws without special tools.

** $\quad$ Ability to Shape refers to the ability to mold the material, e.g. by heating and shaping it.

*** $\quad$ Ability to Tool refers to the ability to sand and saw the product.

Competitive Ranking: Wood Particleboard refers to how wooden particleboard ranks for this requirement.

Competitive Ranking: Synthetic Particleboard refers to how synthetic particleboard ranks for this

Table 2 shows the QFD matrix for the synthetic particleboard. It shows a correlation matrix that links customer needs with manufacturing steps in the production of synthetic particleboard. Typically this matrix shows a correlation of requirements with product components, but in this case manufacturing steps influence the features of the product. The degree of correlation between each customer requirement and each manufacturing step is determined by engineers in product development and manufacturing. For this example the researchers determined the correlations based on various testing results.

Table 2

QFD Matrix for Synthetic Particleboard - Correlation Matrix for the Influence of Manufacturing Steps on Customer Requirements

\begin{tabular}{|c|c|c|c|c|}
\hline $\begin{array}{l}\text { Manufacturing Steps } \\
\text { Requirement }\end{array}$ & Web Formation & Temperature & Pressure & $\begin{array}{l}\text { Surface } \\
\text { Treatment }\end{array}$ \\
\hline Strength & an & man & ma & \\
\hline Screw Withdrawal Resistance & an & घna & ma & $\square$ \\
\hline Nail Withdrawal Resistance & $\mathbf{m}$ & ma & ma & \\
\hline Ease of Nailing* & & $\square$ & ! & ma \\
\hline Ease of Screwing* & & m & a & ma \\
\hline Weight/Ease of Handling & $\square$ & $\square$ & ma & \\
\hline Water Resistance & & घ! & m & 口 \\
\hline Ability to Shape** & & घn日 & ! & $\square$ \\
\hline Ability to Tool ${ }^{* * *}$ & & $\square$ & $\mathbf{m}$ & an \\
\hline
\end{tabular}

$\begin{array}{ll}\text { mun } & =\text { Strong correlation } \\ \text { mI } & =\text { Moderate correlation } \\ \text { m } & =\text { Weak correlation }\end{array}$

When linking the relative ranking of the customer requirements from table 1 with the degree of correlation of the requirement with the different manufacturing steps in table 2, it is possible to deduct how important specific manufacturing steps are to satisfying customer requirements overall. This step constitutes a functional cost analysis of the manufacturing steps, and the results are shown in the summary table 3 . The higher values indicate a higher importance in achieving customer satisfaction, and these steps should then be allowed a higher portion of the manufacturing cost. 
Table3

Results of the Functional Cost Analysis of Manufacturing Steps

\begin{tabular}{|l|l|l|l|l|l|}
\hline Manufacturing Steps & Web Formation & Temperature & Pressure & $\begin{array}{l}\text { Surface } \\
\text { Treatment }\end{array}$ & $\begin{array}{l}\text { Relative } \\
\text { Ranking }\end{array}$ \\
\hline Component Value & $13.1 \%$ & $33.2 \%$ & $32.9 \%$ & $20.8 \%$ & $100 \%$ \\
\hline
\end{tabular}

(Note: The complete matrix available upon request from the authors.)

In this case the table shows the significance of temperature and pressure during the manufacture of synthetic particleboard from an engineering perspective and the impact they will have on customer requirements.

A subsequent step compares the perceived value the components (or manufacturing steps) contribute to the product with the actual cost of these steps. Table 4 shows the relative value of each manufacturing step and the actual cost of this step. The cost is expressed as a percentage of the total cost (respectively the total value). The actual cost is based on a subjective estimation, as some of the equipment needed for full-scale production of the synthetic particleboard does not exist yet. By dividing the relative value by the actual cost one finds a value index. Close to 1 , the value index shows that the cost reflects the value of this step to the customer. If the value index is below 1 (cost higher than component's value), the cost of this manufacturing step needs to be reduced. If the value index is higher than 1 (cost less than component's value), the component or manufacturing step needs to be enhanced. The purpose of the value index is not to reduce overall cost but to distribute the cost portions according to the perceived value for the customer.

Table 4

Value Index for Synthetic Particleboard

\begin{tabular}{|l|l|l|l|}
\hline Manufacturing Step & Actual Cost (\%) & Relative Value (\%) & Value Index \\
\hline Web Formation & $35.0 \%$ & $13.1 \%$ & 0.37 \\
\hline Temperature & $25.0 \%$ & $33.1 \%$ & 1.32 \\
\hline Pressure & $28.0 \%$ & $32.8 \%$ & 1.17 \\
\hline Surface Treatment & $12.0 \%$ & $20.7 \%$ & 1.73 \\
\hline
\end{tabular}

In this case the value index shows that the cost of the manufacturing step "Web Formation" clearly exceeds the value the customers obtain from it, while the surface treatment could be enhanced. It also indicates that the temperature step could be enhanced in order to meet the customer requirements better.

The case study shows how target-costing concepts can be used not only for traditional product components, but also to analyze different manufacturing steps. The results of the QFD matrix also aid in assessing the original target market. In the illustrated case it will be necessary to focus on a different segment where traditional tools are less important, and water resistance and the ability to shape the material are more important.

\section{Conclusion}

Total cost management is a feasible approach of integrating environmental preservation activities over the entire product life cycle into corporate long-term strategies. Environmental conscious manufacturing is made possible through TCM because it seeks to reduce overall product life cycle costs and conserve resources.

The case presented in the study explores the possibility of transforming a specific textile waste product into a useful product. Although the evaluated example has not been commercialized, this research shows how target cost management can be used to promote the development of commercially viable and environmentally friendly products in an effort to recycle textile wastes. This case demonstrates that TCM offers a dynamic modeling approach that will adjust to technological innovation. TCM helps build a corporate culture that stimulates creativity and proactively manages technological innovations that are beneficial to the environment. 
As the views of business ethics and social responsibility evolve and as government regulations change, TCM helps top management strategize and communicate its commitment on sound environmental policies to the entire organization. TCM also creates a supportive environment for continuous improvement in search of innovative solutions to eliminate wastes through effective planning and prevention.

\section{References}

1. Anderson, S.W. and K. Sedatole. 1998. Designing Quality into Products: The Use of Accounting Data in New Product Development, Accounting Horizons (September): pp. 213-233.

2. Ansari, S. L. et al., Target Costing, The Next Frontier in Strategic Cost Management, Chicago, London, Singapore, 1997, pp. $20 \mathrm{ff}$.

3. Burgelman R.A. and M.A. Maidique. 1988. Strategic Management of Technology and Innovation. Homewood: Richard D. Irwin, Inc.

4. Chen, A.Y., T. Romocki and G. Zuckerman. 1997a. An Examination of U.S.-based Japanese Subsidiaries as Evidence of The Transfer of Japanese Strategic Cost Management to the United States in the Advanced Manufacturing Environment, The International Journal of Accounting, Volume 32, No.4, pp. 417-440.

5. Chen, A.Y., R.B. Sawyers and P.F. Williams. 1997b. Reinforcing Ethical Decision Making Through Corporate Culture, Journal of Business Ethics, 16, pp. 855-865. Journal of Business Ethics, 16 1997, pp.855-865.

6. Clickforsteel.com. http://clickforsteel.com/htms/index.asp (November 19, 2001).

7. Cooper, R. and R.I. Slagmulder. 1997. Target Costing and Value Engineering. Montvale: The IMA Foundation for Applied Research, Inc.

8. Freeman III, A.M., D. Burtraw, W. Harrington, and A.J. Krupnick. 1992. Accounting for Environmental Costs in Electric Utility Resource Supply Planning, working paper, Resources for the Future, Washington, D.C.

9. Heinisch, M., Hergeth, H., Smith, G., Particleboards from Waste Textile Fibers, accepted for publication in Melliand International.

10. Hergeth, H., 2001. Launching Products towards the Right Target, Proceedings of the $81^{\text {st }}$ Annual Conference of the Textile Institute, Melbourne, Australia, April $1^{\text {st }}$ through $4^{\text {th }}, 2001$.

11. Hunt C. and E. Auster. 1990. Proactive Environmental Management: Avoiding the Toxic Trap, Sloan Management Review (Winter): pp. 7-18.

12. Monden, Y. 1989. Total Cost Management System in Japanese Automobile Corporations, in Japanese Management Accounting, Y. Monden and M. Sakurai, eds. Cambridge: Productivity Press, pp. 15-33.

13. Monden, Y. and K. Hamada. 1991. Target costing and Kaizen Costing in Japanese Automobile Companies, Journal of Management Accounting Research, 3 (Fall): pp. 16-34.

14. RAGauction.com. http://www.recycleauction.com/ (November 19, 2001)

15. Solid Waste.com. http://www.solidwaste.com/content/homepage/default.asp (November 19, 2001)

16. Shank, J.K. and J. Fisher. 1999. Case Study: Target Costing As A Strategic Tool, Sloan Management Review (Fall): pp. 73-82.

17. Stratton, B. 1991. Going Beyond Pollution Control, Quality Progress Vol.25, No.4, (April): pp. 18-20.

18. Tushman, M.L. and W.L. Moore. 1988. Readings in the Management of Innovation, Second Edition. Cambridge: Ballinger Publishing Company.

19. Wagner, S. 1993. Improvements in Products and Processing to Diminish Environmental Impact. GOTTECH Conference, Raleigh, NC (November 11-12).

20. Duales System Deutschland AG, http://www.gruener-punkt.de (November 19, 2001)

21. Yoshikawa, T., J. Innes, and F. Mitchell. 1990. Cost Tables: A Foundation of Japanese Cost Management, Journal of Cost Management for the Manufacturing Industry, Vol.4, No.3, (Fall): pp. 30-36.

\section{Biographies}

1. Al Y.S. Chen is a Professor of Accounting at the North Carolina State University. He received a Ph.D. in accounting from the Georgia Institute of Technology in 1989. His current research interests include ecommerce, supply-chain management, cost management systems of multinational companies, and total cost management. 
2. Helmut Hergeth is an Associate professor in the Textile and Apparel, Technology and Management within the College of Textiles at North Carolina State University. He received a Ph.D. in management and economics from the Westfälische Wilhelms-Universität in Germany in 1986. His research interests include management and costing issues in textiles and product development.

3. Gilroy J. Zuckerman is the Associate Dean of College of Management at the North Carolina State University. He received a Ph.D. in economics from North Carolina State University in 1974. His current research interests include cost management systems of multinational companies, total cost management, and cooperative learning strategies.

\section{Notes}

